Article

\title{
Teacher Confidence in Professional Training: The Predictive Roles of Engagement and Burnout
}

\author{
Caterina Fiorilli ${ }^{1, *} \mathbb{0}$, Ilaria Buonomo ${ }^{1} \mathbb{D}$, Luciano Romano ${ }^{1}\left(\mathbb{D}\right.$, Ylenia Passiatore ${ }^{2}$, \\ Domenica Fioredistella Iezzi ${ }^{3}$, Paolo Emilio Santoro ${ }^{4} \mathbb{D}$, Paula Benevene ${ }^{1}$ and Alessandro Pepe ${ }^{5}$ \\ 1 Department of Human Sciences, University of Rome, LUMSA, 00193 Rome, Italy; \\ i.buonomo1@lumsa.it (I.B.); 1.romano@lumsa.it (L.R.); benevene@lumsa.it (P.B.) \\ 2 Department of Educational Sciences, Università di Roma Tre, 00100 Rome, Italy; y.passiatore@gmail.com \\ 3 Dipartimento di Ingegneria dell'Impresa, Università di Roma Tor Vergata, 00133 Rome, Italy; \\ stella.iezzi@uniroma2.it \\ 4 Department of Women's, children's and public health studies, Fondazione Policlinico Universitario A. \\ Gemelli IRCCS, 00168 Rome, Italy; paoloemilio.santoro@unicatt.it \\ 5 Department of Human Sciences, University of Milan-Bicocca, 20123 Milan, Italy; alessandro.pepe1@unimib.it \\ * Correspondence: fiorilli@lumsa.it
}

Received: 23 June 2020; Accepted: 1 August 2020; Published: 6 August 2020

\begin{abstract}
Teachers' work engagement positively impacts teachers' attitudes towards their job. Nevertheless, teachers may experience burnout during their career, which negatively impacts their professional learning opportunities. In this study we investigated the relationship between teachers' levels of burnout, work engagement, and their confidence in in-service training in a sample of Italian teachers. We expected that burnout mediated the relationship between work engagement and teachers' confidence in training. A total of 481 teachers completed self-report questionnaires about engagement and burnout, with an ad hoc Confidence in Training Index developed to assess their attitudes towards professional development courses. The mediation analysis confirmed that the teachers' levels of burnout mediated the relationship between their work engagement and their confidence in in-service training. Findings suggest that teacher confidence in policies about professional training should be evaluated by taking into account their level of engagement and burnout.
\end{abstract}

Keywords: work engagement; burnout; professional development; school teachers

\section{Introduction}

Despite most research on human capital focusing on profit and nonprofit organizations, governmental institutions are required to address human capital in order to effectively deliver their services. Indeed, human capital approaches encourage investing in people as capital, thus influencing the organizational practices aimed at developing human resources and the organization in general [1,2]. In the context of educational institutions, teachers represent the most relevant human capital, as they impact the quality of the educational services delivered to students, families, and the community [3,4]. In this regard, for this reason, policies aimed at recognizing and addressing teacher development are crucial for the organizational performance of schools, as well as for teacher well-being. Thus, the attitudes towards in-training experiences play a major role in the effectiveness of human capital development initiatives. This link is particularly relevant when considering the peculiar and specific professional experience of teachers.

Indeed, recent findings suggest that teachers begin their professional careers with high levels of work engagement and commitment, which give them the energy to cope with stressful events. Nonetheless, teaching is known to be a stressful occupation and teachers' exposure to multiple sources 
of stress can lead them to experience burnout. If schools systematically offer professional development opportunities-Delivering additional personal and professional resources-To teaching staff, this can reduce the risk of burnout. However, for professional development to be effective, teachers must have positive emotions about and hold positive attitudes towards these training programs. The aim of the current study was to investigate the relationships between teachers' work engagement, levels of burnout, and attitudes towards training.

The choice of teaching as a profession is largely underpinned by intrinsic motivation [4-8], which leads teachers to be deeply engaged with their work (i.e., invested in their own professional development) as well as committed to promoting their students' growth and development [9]. According to Tschannen-Moran and Hoy [10], engaged teachers are altruistically motivated to do their job, viewing their work as making a key contribution to social progress and development. Teachers' work engagement is broadly defined as their general commitment to their work [11,12]. More specifically, it has been described as "a positive, fulfilling, work-related state of mind that is characterized by vigor, dedication, and absorption" ([12], p. 74). Vigor implies bringing high levels of energy and mental resilience to bear on one's job and displaying persistence in dealing with difficulties. Dedication means being deeply involved in one's work and getting a sense of meaning, enthusiasm, inspiration, pride, and challenge from it. Finally, absorption entails being fully focused on one's job [13]. Engaged workers experience positive emotions, are more active [14], happy [15], more open to new experiences [16], and take a more creative approach to job opportunities [17]. Consequently, teachers' levels of work engagement may impact their professional development trajectories [18] and learning opportunities.

Nevertheless, being engaged at the beginning of their career does not prevent teachers from later experiencing burnout. Research has consistently found that the more teachers are exposed to sources of stress, the more they are at risk of burnout (e.g., [19]). Sources of stress for teachers can include class size, student learning disabilities, student behavior issues, conflict amongst colleagues, problematic relationships with parents, and time pressures (e.g., [20]). Aspects of education policy, such as continual legislative changes concerning teacher recruitment, poor remuneration, and a lack of social recognition, also represent stressors for teachers (e.g., [21,22]).

Work burnout is broadly defined as a syndrome characterized by emotional exhaustion, detachment from work, and reduced personal accomplishment $[23,24]$. A recent approach to assessing workers' burnout looks at fatigue and exhaustion in three specific areas, namely, the personal, work, and client domains [25]. Specifically in relation to teachers [21], the first of these dimensions captures teachers' emotional exhaustion in relation to their lives in general, while the other two dimensions tap into their difficulty in coping with events in school life and managing negative emotions and behaviors towards their colleagues and students in terms of their self-perceived physical and psychological fatigue.

Both work engagement and burnout have an impact on teachers' attitudes towards their job: while engaged teachers are motivated to improve their professional competence, burned-out teachers are more likely to reject professional learning opportunities [26-28].

Teacher professional development encompasses teacher recruitment processes, induction and mentoring, professional learning, as well as career and leadership development. In light of OECD data from across high- and low-performing countries, it is recognized that teacher training is a key factor contributing to differences among school systems. Consequently, each country is addressing this issue by developing policies for delivering effective teachers to its education system [29]. Indeed, research in countries with the best-performing students has shown that teacher professional development makes a crucial difference to the outcomes (e.g., [18]). The OECD [4] itself has reported that the more teachers' professional development is catered for (e.g., by means of workshops, practical training, tutoring, etc.), the more the students achieve.

Forming effective teachers requires delivering in-service training and resources for addressing school-related problems. Although in-service training is mandatory for teachers in many countries, including Italy, attending a training course does not necessary boost teachers' confidence nor will 
teachers necessarily perceive it as effectively helping them to do their job. Numerous authors maintain that effective professional development interventions can lead to a change in teachers' educational practices, provided the teachers have a positive attitude towards the training activities (e.g., [30,31]).

Despite the close relationship between effective training and teachers' professional development, no previous studies have focused on teachers' trust in formally organized training or the extent to which they view it as a help to their everyday educational practice. First, given the current lack of instruments for assessing teachers' attitudes towards their in-service training, we set out in the current study to develop an ad hoc measure and to evaluate its psychometric characteristics. Secondly, we investigated the relationships between teachers' levels of work engagement, burnout, and confidence in the in-service training they had received. More specifically, we expected that teachers' burnout scores (in the personal, work-related, and student-related domains) would be negatively associated with their work engagement (in terms of vigor, dedication, and absorption). Furthermore, we expected that poor confidence in their in-service training would be positively associated with burnout and negatively associated with work engagement. Crucially to our research design in the current study, we expected that burnout would mediate the relationship between work engagement and teachers' confidence in training. Specifically, we expected that teachers with low work engagement would display high levels of burnout that, in turn, would negatively influence their confidence in training.

\section{Materials and Methods}

\subsection{Participants}

The current study included 481 teachers ( $89 \%$ females), ranging in age from 24 to 66 $(\mathrm{M}=46.9$ years, $\mathrm{SD}=8.7)$. The majority held a degree $(74.2 \%)$, and only $25.8 \%$ a high school diploma. Participants were employed in kindergarten $(9.6 \%)$, primary school $(45.5 \%)$, lower secondary (middle) school (18.5\%), and high school (26.4\%). Work experience ranged from 1 to 42 years $(\mathrm{M}=18.55$ years, $\mathrm{SD}=10.1)$.

\subsection{Procedure}

We collected the data in ten schools in Northern, Central and Southern Italy. We contacted the teachers after initial approval by their school principals. We administrated all the questionnaires individually to the teachers who completed the paper-pencil questionnaires. This study was conducted in accordance with the requirements of privacy and informed consent laid down by Italian law (Law Decree DL-196/2003). Teachers were assured that participation was optional and that their responses would remain anonymous. The current study is part of wider ranging research that include further variables and instruments.

\subsection{Measures}

Three self-report questionnaires were administered: the Copenhagen Burnout Inventory [25], Utrecht Work Engagement [32], and the Index of Confidence in Training.

Copenhagen Burnout Inventory (CBI): The CBI ([25]; Italian version by [21]) is a 19-item inventory measuring three sub-dimensions of burnout (personal burnout, work-related burnout, and student-related burnout). It is composed of three subscales with a total of 19 items, each rated on a 5-point Likert scale. The first dimension is composed by six items concerning the physical and psychological fatigue and overall exhaustion experienced by an individual (e.g., How often do you feel tired?; How often do you feel worn out?). The second dimension is composed of seven items concerning the physical and psychological fatigue experienced by respondents due to their teaching work (e.g., Do you feel burnt out because of your work?; Do you feel worn out at the end of the working day?). Finally, the third dimension include six items evaluating the physical and psychological fatigue experienced by people who work with students (e.g., Do you find it hard to work with students?; Are you tired of working with students?). Participants respond using a 5-point scale, ranging from 
1 (never) to 5 (always). Alpha coefficients were 0.92 for the full-scale CBI, 0.90 for personal burnout, 0.72 for work-related burnout, and 0.82 for student-related burnout.

Utrecht Work Engagement Scale (UWES-17): Work engagement was assessed by UWES-17 ([32]; Italian version by [33]). This 17-item questionnaire measures three subscales of engagement: vigor (six items), dedication (five items), and absorption (six items). All items are scored on a 7-point Likert scale ranging from 0 (never) to 6 (always). Alpha coefficients were 0.95 for the full-scale UWES-17, 0.87 for vigor, 0.92 for dedication, and 0.87 for absorption.

Index of Confidence in Training (ICT): The Index of Confidence in Training (ICT) was designed through a three-step process: (1) analysis of the literature and identification of the theoretical framework; (2) definition of the items and development of the index; and (3) testing the model of measurement according to confirmatory factor analysis procedures. First, an analysis of both the theoretical and empirical literature addressing teachers' professional development was undertaken. After an extensive review (e.g., $[14,15,17,18,29-31])$, we selected six topics as the start-point for measuring teachers' confidence in attempted training (i.e., how training has impacted on teaching style and practices, learning motivation, engagement at work, discovering new knowledge, changing mind, and self-confidence). In the second step, a focus group composed of experienced teachers and trainers generated statements focusing on the teachers' confidence in the attempted training. The authors examined and discussed the proposed items in accordance with the main core of the under-construction index. The item generation process resulted in an 11-item scale (see Appendix A). The items were preceded by the following introductory statement: "Making a balance of the different training moments in the course of your experience, can you indicate to what extent you agree with the following statements?". Participants were asked to express their level of agreement on a 4-point Likert scale, where 1 = disagree, 2 = little agree, $3=$ enough agree, and $4=$ agree. The sum of the agreement levels indicated the perceptions of training and it was labeled as the Index of Confidence in Training. Finally, (step three) the model of measurement composed of two latent factors (personal growth in training and professional growth in training) was estimated by using confirmatory factor analysis ([34]; see for details [35,36]). The results of the analysis $(\chi 2(35)=113.6, p<0.05, \mathrm{NFI}=0.936, \mathrm{NNFI}=0.954$, $\mathrm{CFI}=0.955$, RMSEA $=0.070$, and $90 \% \mathrm{CI}=0.055-0.084$ ) supported the adoption of the model as a mean to assess teachers' confidence in training. Factor loadings ranged from 0.60 ("they made me feel less motivated about teaching"-ITEM 2 reverse, i.e., the numerical scoring scale runs in the opposite direction) to 0.75 ("they increased my confidence in my own competencies"). In the present study, the reliability alpha coefficients were 0.815 for personal growth in training and 0.812 for professional growth in training. Reliability for the unidimensional cumulate score was 0.832 .

\subsection{Strategy of Data Analyses}

In keeping with current literature, the conceptual structure to be tested was modelled with three latent endogenous variables and eight empirical indicators. Starting from the left to the right (see Figure 1), work engagement was measured by vigor, dedication, and absorption, and it was considered as the explanatory variable. Then, teachers' burnout levels (as the mediator) was conceptualized as estimated by personal burnout, work-related burnout, and student-related burnout. Finally, the confidence in training was used as the target latent variable and it was measured by means of personal and professional growth in training. 


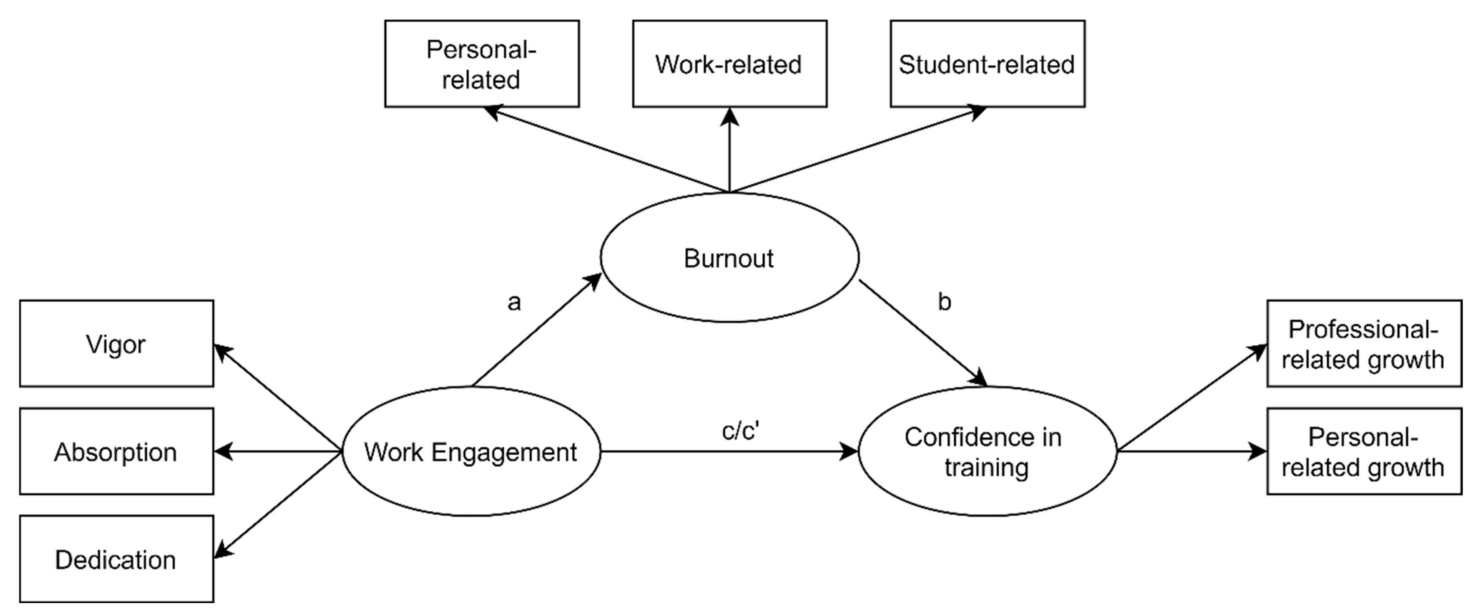

Figure 1. Conceptual mediation model: Levels of burnout as a potential mediator of the association between work engagement and confidence in training.

To estimate the hypothesized model, we used Amos 23.0 [37]. According to a multifaceted approach [38], the following criteria were employed to evaluate the goodness of the tested models: x 2 likelihood, Tucker and Lewis Index (TLI), Comparative Fit Index (CFI), Normed Fit Index (NFI), and the Root Mean Square Error of Approximation (RMSEA), with the corresponding confidence intervals. We considered the model as acceptable for TLI, NFI, and CFI values greater than 0.95 [39] and for RMSEA values lower than 0.08 [40]. In keeping with current practices in SEM (e.g., [41]), we estimated the confidence limits using both Monte Carlo simulation and bootstrapping methods with a set of random samples $(k=500)$. Mediation analysis was conducted by decomposing the total effects among the variables in direct and indirect effects. We also computed Mahalanobis' distance $(p<0.001)$ to identify the multivariate outliers, finding that no cases needed to be removed from the dataset. Finally, we assessed the data for normality of distribution. None of the score sets displayed kurtosis or skewness values exceeding the recommended limits $(-1,+1)$, and consequently the Maximum Likelihood method [42] was adopted to estimate the parameters for the SEM analysis.

\section{Results}

\subsection{Descriptive Statistics and Zero-Order Correlations among Teachers' Engagement, Burnout, and Confidence} in Training

According to the explanatory aims of the current research, the scores for work engagement and professional burnout are firstly presented, in a disaggregated fashion, according to the standard cut-off points in order to offer a portrait of the overall psychological condition of the participants. Then, the aggregate cumulate scores were used in the multivariate statistics and we attempted to model the data. The results for work engagement are summarized in Table 1, whereas the levels of burnout are reported in Figure 2.

Table 1. Synthesis of the Norm Scores for the Utrecht Work Engagement Scale (UWES-17) in Teachers $(\mathrm{N}=481)$.

\begin{tabular}{cccc}
\hline & Vigor (\%) & Dedication (\%) & Absorption (\%) \\
\hline Very low & 7.1 & 1.7 & 2.1 \\
Low & 8.7 & 5.2 & 4.8 \\
Average & 43.5 & 29.3 & 28.7 \\
High & 30.4 & 32.2 & 37.0 \\
Very high & 10.4 & 31.6 & 27.4 \\
\hline
\end{tabular}

Note: Cut-off points from Schaufeli and Bakker, 2003. 


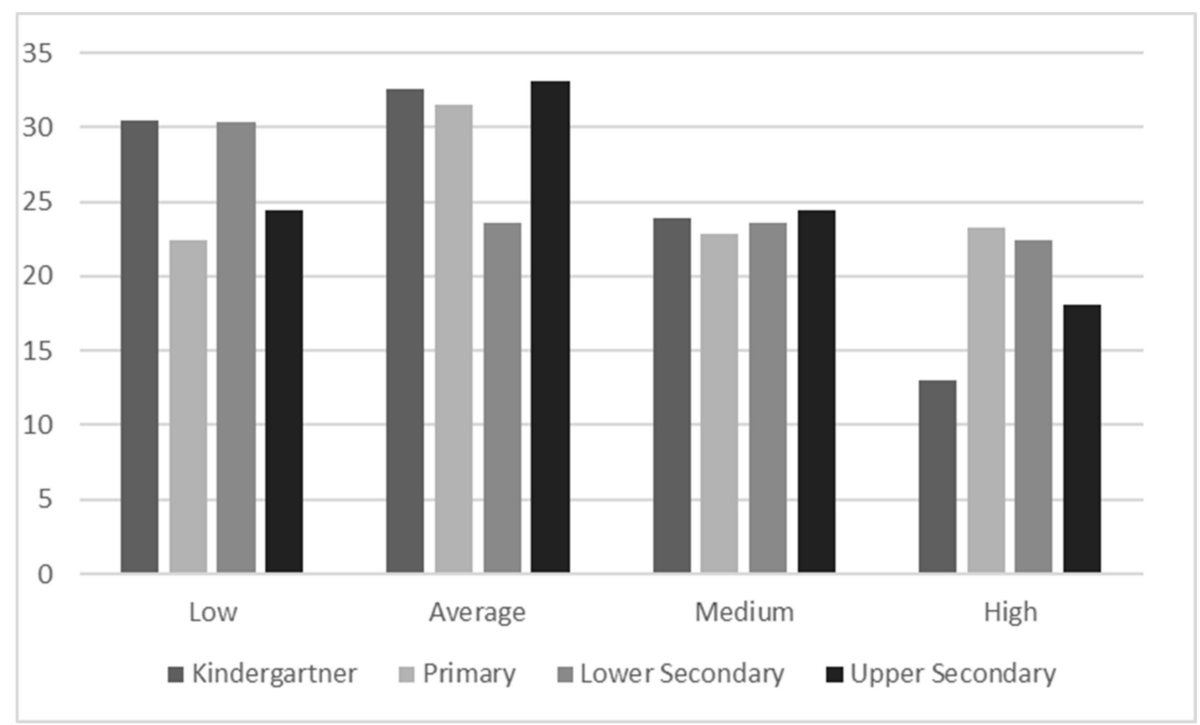

Figure 2. Levels of burnout according to the cut-off scores (low $<40$, average between 41 and 50, medium between 51 and 60, and high $>61$ ). Data are expressed in percentage of teachers included in each category according to school grades.

In general, the participants can be described as having a quite good level of engagement and moderate levels of professional burnout. The analysis of the descriptive data suggested that approximately half of the sample reported "high" or "very high" levels of engagement on all three empirical dimensions of engagement.

Table 2 summarizes the results of the correlational exploratory analysis.

Table 2. Zero-Order Correlations among the Copenhagen Burnout Inventory (CBI), UWES, and Index of Confidence in Training (ICT).

\begin{tabular}{cccccccc}
\hline & $\mathbf{1}$ & $\mathbf{2}$ & $\mathbf{3}$ & $\mathbf{4}$ & $\mathbf{5}$ & $\mathbf{6}$ & $\mathbf{7}$ \\
\hline 1. Personal burnout & 1 & & & & & & \\
2. Work-related burnout & $0.83^{* *}$ & 1 & & & & & \\
3. Student-related burnout & $0.63^{* *}$ & $0.73^{* *}$ & 1 & & & & \\
4. Vigor & $-0.46^{* *}$ & -0.52 & $-0.51^{* *}$ & 1 & & & \\
5. Dedication & $-0.42^{* *}$ & $-0.48^{* *}$ & $-0.52^{* *}$ & $0.83^{* *}$ & 1 & & \\
6. Absorption & $-0.24^{* *}$ & $-0.30^{* *}$ & $-0.34^{* *}$ & $0.81^{* *}$ & $0.78^{* *}$ & 1 & \\
7. Confidence in Training & $-0.34^{* *}$ & $-0.38^{* *}$ & $-0.39^{* *}$ & $0.36^{* *}$ & $0.36^{* *}$ & $0.26^{* *}$ & 1 \\
\hline & & Note: & & &
\end{tabular}

Exploration of zero-order correlations revealed that the three subscales of work engagement (vigor, dedication, and absorption) were positively related with teachers' confidence in the training courses. In fact, positive, medium, and statistically significant correlations were found between confidence in training and the three measures of work engagement. On the contrary, work engagement reported a negative and statistically significant correlation with the burnout measures (personal burnout, work-related burnout, and client-related burnout) meaning that the two latent variables were inversely related. Finally, teachers' burnout levels were negatively associated with confidence in training.

\subsection{Mediation Analysis Results}

According to the procedure of mediation testing, we modelled the hypothesized structural paths (see Figure 1) by estimating (1) the total effect (A) of work engagement on burnout; (2) the total effect 
(B) of burnout on confidence in training; and (3) both the total (C) and the direct $\left(\mathrm{C}^{\prime}\right)$ effects of work engagement on confidence in training.

The model showed an excellent fit to the data $(\chi 2(15)=48.7, p<0.05, \mathrm{NFI}=0.980, \mathrm{CFI}=0.986$, $\mathrm{TLI}=0.974$, and RMSEA $=0.069(0.048-0.092))$, and supported the adoption of the structural model (see Figure 3).

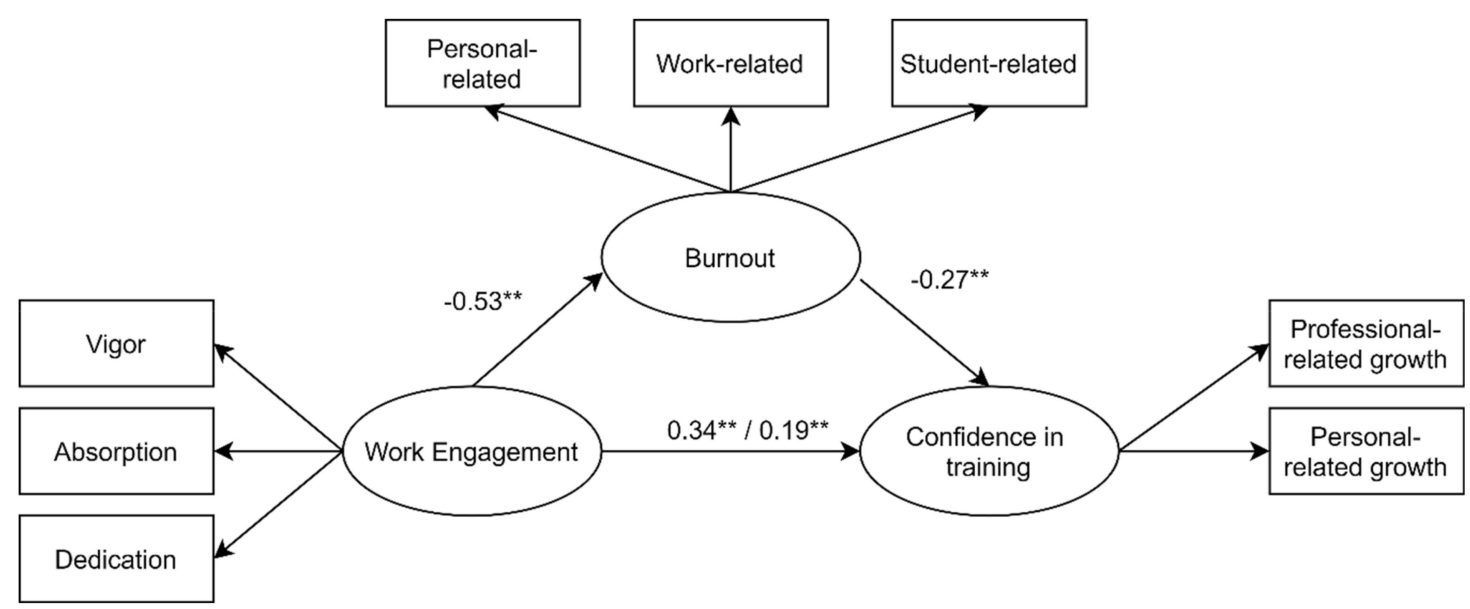

Figure 3. Structural mediation model between work engagement, burnout, and confidence in training $(\mathrm{N}=481)$. The standardized effects are reported. ${ }^{* *} p<0.01$.

The results showed that work engagement and burnout significantly predicted teachers' confidence in training, negatively and positively, respectively. In particular, work engagement reported a statistically significant, negative, and large standardized total effect on both burnout $(\beta=-0.53$, $p=0.005$, and $90 \% \mathrm{CI}=-0.425--0.312)$ and confidence in training $(\beta=0.34, p=0.010$, and $90 \%$ $\mathrm{CI}=0.201-0.601)$. Similarly, burnout levels revealed a statistically significant, negative, and large standardized effect on confidence in training ( $\beta=-0.27, p=0.003$, and $90 \% \mathrm{CI}=-0.738-0.242$ ), meaning that the higher the burnout the lower the perceptions of confidence in training. Finally, the analysis of the direct $(\beta=0.19, p=0.005$, and $90 \% \mathrm{CI}=0.098-0.402)$ and indirect effects $(\beta=0.15$, $p=0.003,90 \% \mathrm{CI}=0.091-0.270$ ) of engagement on confidence in training suggested that a mediating effect of burnout on the relation between work engagement and confidence in training was found. In particular, the ratio between the total and the direct effect indicated that approximately $45 \%$ of the positive effect of work engagement on confidence in training was attenuated by the burnout levels. As a consequence, the hypothesis of mediation was partially supported since data did not reveal a full mediation.

\section{Discussion}

The current study examined how teachers rate their own in-service training, which is mandatory in several education systems around the world, and how their confidence in the professional development courses, as well as the effects of work engagement and professional burnout, impact their scores on confidence towards these in-training courses. Firstly, we designed and validated the Index of Confidence in Training (ICT) to evaluate teachers' attitudes towards professional training. Our findings show a good reliability of the index for both latent factors, i.e., personal and professional growth in training, as well as for the unidimensional measure able to evaluates teachers' perceptions of training. Secondly, as expected, we found a negative association between teachers' work engagement and burnout, as well as a positive association between engagement and confidence in training levels. Similarly, as expected, our results show that teachers' burnout level is negatively associated with their confidence in training. Finally, the main core of the current study focused on the mediating role of teachers' burnout. Our findings show its partial mediation, affecting the relationship between work 
engagement and confidence in training. In the following sections, we discuss the implications of our findings for teacher professional development.

\section{Between Teachers' Engagement and Confidence in Training: The Dramatic Impact of Burnout}

Coherently with our hypothesis, in the current sample of Italian teachers, work engagement was negatively associated with burnout. It is an expected result in line with abundant international findings that have shown that the more workers are engaged, the less burnout symptoms they experience during their career (e.g., [26-28,43-47]). Furthermore, our findings have shown that engaged teachers express high confidence towards professional training. This result was partially supported by previous research that has shown that teachers with high work engagement are more likely to display positive attitudes towards their job in terms of persistence, productivity, job satisfaction, positive work attitudes, organizational commitment, and psychological well-being at work [31,48-51]. More specifically, in the current study, we analyzed whether teachers' work engagement was associated with a specific attitude towards their professional career, i.e., in-service training. Our findings show that engaged teachers are more likely to be confident in their professional training. Effectively, when they are asked to take stock of the different training moments in their professional career, engaged teachers strongly agree with ICT items like "they enabled me to discover new topics; they enabled me to try out new things in the classroom; they increased my confidence in my own competencies".

Similarly, as expected, teachers with high levels of burnout show lower confidence in professional training than their colleagues. More specifically, they strongly agree with ICT statements like "they didn't help me to change my attitudes and styles of teaching; I thought that I would never attend such demanding courses again; I found it difficult to apply the course contents with my students." Effectively, burned-out teachers are characterized by detachment from their work (e.g., [28-31]) and cynicism (e.g., [52-54]) regarding their relationships with colleagues and students. In this regard, our results seem to confirm that it might be more difficult for teachers who are experiencing exhaustion and demotivation towards their work to be involved in professional learning experiences.

The main result of our study is that teachers' burnout has a significant impact on the positive relation between engagement and confidence in training, specifically by having a detrimental effect on this positive relation. More specifically, while teachers' engagement is, as expected, directly predictive of their confidence in training, it also has an indirect effect through the mediating role of burnout. In other words, almost half of the positive effect of engagement on confidence in training is weakened by their burnout level. Nevertheless, our results add some new perspectives regarding the burnout dimension focusing on teachers' attitudes towards professional development. The findings are in line with previous research that has shown the detrimental effects of burnout on teachers' commitment to their job [52,55-60]. Yet, results shed a light on their demotivation to adopt novelty in their work, coming from professional training as well as from their colleagues' suggestions [61]. Conversely, our findings further support this dimension by showing how burned-out teachers have less motivation to positively advance themselves through professional training (on both dimensions of personal and professional growth). In our opinion, policies on teacher professional development needs to take into account the teachers' attitudes towards in-service training, which, in turn, may significantly impact on the effectiveness of the training (e.g., [31]).

\section{Conclusions}

Overall, negative attitudes towards their job hinders teachers from actively pursuing job resources (e.g., professional training opportunities). Principals, practitioners, and education policy makers should bear in mind that teachers' attitudes towards professional learning experiences are influenced by their level of burnout during training.

One of the key challenges in improving education today is optimizing teachers' professional development. It has been documented that countries with high-performing education systems implement professional development policies [4]. Furthermore, previous international studies have 
highlighted the important role played by teacher professional development in improving teachers' beliefs and fostering their relations with students [22,31]. Despite this, there is research evidence that both novice and experienced teachers tend to not feel sufficiently prepared to face the daily challenges at work (e.g., [62,63]). This suggests that teachers perceive their ongoing professional training as ineffective or not effective enough.

Policies providing for teacher professional development should take into account the principle that effective training requires a positive attitude and confidence on the part of the attending teachers. Scholars (e.g., [30]) have found that effective training can lead to a change in teachers' educational practices, provided that teachers have a positive attitude towards their own learning activities. In our opinion, training can positively impact teachers' professional development when it focuses on their professional well-being in the first instance [64]. Negative emotions towards one's job can undermine the impact of any professional learning opportunity.

As proposed by Korthagen [65], a key component of teacher development should be enhancing teachers' ability to recognize their core personal strengths (see [66]), and to draw on them in their everyday educational practice. Research assessing a strengths-based approach to professional learning in teachers has shown that an increased ability to identify their core strengths in their daily work at school helps teachers to feel more autonomous, competent, and effective as professionals [67]. Overall, it seems of great interest to develop a multidimensional approach to teacher development and learning that integrates the professional and personal aspects of teaching (see [65]).

Finally, in the case of other empirical studies, a number of limitations should be addressed in considering the results. First, the participants were recruited as a convenience sample, meaning that the results should be considered more in terms of transferability rather than generalizability [68]. We tried to compensate for this issue by recruiting a large sample of teachers from different school grades following the principle of maximizing sampling heterogeneity. Further studies are needed to comprehend whether and to what extent work engagement and burnout affect confidence in training in the general population of teachers. A second limitation is linked to the use of quantitative self-reports as the principal method for data gathering. Mono-method quantitative studies are vulnerable to common method variance (CMV; [69]), meaning that associations between variables can be distorted. Future studies examining the pattern of association from a mixed-method research design are consequently welcome. Moreover, the present study was cross-sectional and consequently the measures were gathered at one single point in time. Further research is needed to observe variables longitudinally by perhaps including the direct measures of training effectiveness for individual teachers. Finally, it could be interesting to analyze how teachers change their attitudes towards professional training by further taking into account their previous training experiences.

Author Contributions: Conceptualization, C.F.; methodology, D.F.I. and A.P.; validation, I.B., P.B. and L.R.; formal analysis, A.P.; investigation, C.F., Y.P. and P.E.S., and L.R.; writing-Original draft preparation, C.F., Y.P. and I.B.; writing-Review and editing, P.B. and P.E.S.; supervision, A.P. and P.B. All authors have read and agreed to the published version of the manuscript.

Funding: This research received no external funding.

Conflicts of Interest: The authors declare no conflict of interest.

\section{Appendix A}

\section{Instructions}

"In terms of providing an overall assessment of the training courses you have been offered during your teaching career, could you please indicate to what extent you agree with the following statements?"

\section{Scores}

A 4-point Likert scale where 1 = disagree, 2 = don't agree very much, $3=$ quite agree, $4=$ agree. 
Items

\begin{tabular}{ll}
\hline 1. (En.) & they didn't help me to change my attitudes and styles of teaching (reverse) \\
1. (It.) & non hanno contribuito a cambiare le mie abitudini e stili di insegnamento \\
2. (En.) & they made me feel less motivated about teaching (reverse) \\
2. (It.) & hanno peggiorato la mia motivazione verso la scuola \\
3. (En.) & they disappointed me because they fell short of my expectations (reverse) \\
3. (It.) & mi hanno deluso perché al di sotto delle aspettative \\
4. (Eng.) & they enabled me to discover new topics \\
4. (It.) & mi hanno permesso di conoscere nuovi temi \\
5. (En.) & they enabled me to try out new things in the classroom \\
5. (It.) & mi hanno permesso di sperimentare nuove cose in aula \\
6. (En.) & they increased my confidence in my own competencies \\
6. (It.) & hanno aumentato la mia fiducia sulle mie competenze \\
7. (En.) & they made me feel like giving up this job (reverse) \\
7. (It.) & mi hanno fatto venir voglia di abbandonare il lavoro \\
8. (En.) & I felt a sense of helplessness about all there is to be done at school (reverse) \\
8. (It.) & ho provato una sensazione di impotenza rispetto a quanto c'è da fare a scuola \\
9. (En.) & I thought that I would never attend such demanding courses again (reverse) \\
9. (It.) & ho pensato che non avrei più seguito corsi così impegnativi \\
10. (En.) & I found them too theoretical and distant from educational practice (reverse) \\
10. (It.) & troppo teorici e distanti dalla pratica educativa \\
11. (En.) & I found it difficult to apply the course contents with my students (reverse) \\
11. (It.) & ho avuto difficoltà ad applicare con gli studenti ciò che ho ascoltato \\
\hline
\end{tabular}

\section{References}

1. Aliaga, A.O. Human capital, HRD and the knowledge organization. In Proceedings of the Academy of Human Resource Development 2001, Baton Rouge, LA, USA, 7 May 2001; pp. 427-434.

2. Engelbrecht, H.-J. Human Capital and Economic Growth: Cross-Section Evidence for OECD Countries. Econ. Rec. 2003, 79, S40-S51. [CrossRef]

3. Organisation for Economic Co-operation and Development Staff. OECD Creating Effective Teaching and Learning Environments: First Results from TALIS; OECD Publishing: Paris, France, 2009.

4. Organisation for Economic Co-operation and Development Staff. OECD Factbook 2018: Economic, Environmental and Social Statistics; OECD Publishing: Paris, France, 2018.

5. Darling-Hammond, L.; Youngs, P. Defining "Highly Qualified Teachers": What Does "Scientifically-Based Research" Actually Tell Us? Educ. Res. 2002, 31, 13-25. [CrossRef]

6. Massari, G.A. Key factors of preschool and primary school teachers job satisfaction. Ped. Acta 2015, 5, $27-40$.

7. Organisation for Economic Co-operation and Development Staff OECD Factbook 2005: Economic, Environmental and Social Statistics; OECD Publishing: Paris, France, 2005.

8. Spear, M.; Gould, K.; Lee, B. Who Would be a Teacher?: A Review of Factors Motivating and Demotivating Prospective and Practising Teachers; NFER: Slough, UK, 2000; ISBN 0700530142.

9. Fiorilli, C.; Farina, E.; Buonomo, I.; Costa, S.; Romano, L.; Larcan, R.; Petrides, K.V. Trait emotional intelligence and school burnout: The mediating role of resilience and academic anxiety in high-school. Int. J. Environ. Res. Public Health 2020, 17, 58. [CrossRef]

10. Tschannen-Moran, M.; Hoy, A.W. Teacher efficacy: Capturing an elusive construct. Teach. Teach. Educ. 2001, 17, 783-805. [CrossRef]

11. Maslach, C.; Jackson, S.E.; Leiter, M.P. Maslach Burnout Inventory manual, 3rd ed.; Consulting Psychologist Press: Palo Alto, CA, USA, 1996.

12. Schaufeli, W.B.; Salanova, M.; González-Romá, V.; Bakker, A.B. The measurement of engagement and burnout: A two sample confirmatory factor analytic approach. J. Happiness Stud. 2002, 3, 71-92. [CrossRef]

13. Schaufeli, W.B.; Bakker, A.B. Defining and measuring work engagement: Bringing clarity to the concept. In Work Engagement: A Handbook of Essential Theory and Research; Bakker, A.B., Leiter, M.P., Eds.; Psychology Press: New York, NY, USA, 2010.

14. Albrecht, S. Handbook of Employee Engagement; Edward Elgar Publishing: Cheltenham, UK, 2010. 
15. Rodríguez-Muñoz, A.; Sanz-Vergel, A.I.; Demerouti, E.; Bakker, A.B. Engaged at work and happy at home: A spillover-crossover model. J. Happiness Stud. 2014, 15, 271-283. [CrossRef]

16. Fredrickson, B.L. The role of positive emotions in positive psychology: The broaden-and-build theory of positive emotions. Am. Psychol. 2001, 56, 218-226. [CrossRef]

17. Bakker, A.B.; Xanthopoulou, D. Creativity and charisma among female leaders: The role of resources and work engagement. Int. J. Hum. Resour. Manag. 2013, 24, 2760-2779. [CrossRef]

18. Heinz, M. Why choose teaching? An international review of empirical studies exploring student teachers' career motivations and levels of commitment to teaching. Educ. Res. Eval. 2015, 21, 258-297. [CrossRef]

19. Bakker, A.B.; Schaufeli, W.B.; Sixma, H.J.; Bosveld, W.; van Dierendonck, D. Patient demands, lack of reciprocity, and burnout: A five-year longitudinal study among general practitioners. J. Organ. Behav. 2000, 21, 425-441. [CrossRef]

20. Benevene, P.; Fiorilli, C. Burnout syndrome at school: A comparison study with lay and consecrated italian teachers. Mediterr. J. Soc. Sci. 2015, 6, 501-506. [CrossRef]

21. Fiorilli, C.; de Stasio, S.; Benevene, P.; Fioredistella-Iezzi, D.; Pepe, A.; Albanese, O. Copenhagen Burnout Inventory (CBI): A validation study in an Italian teacher group. TPM Test. Psychom. Methodol. Appl. Psychol. 2015, 22, 537-551. [CrossRef]

22. Maaranen, K.; Kynäslahti, H.; Byman, R.; Jyrhämä, R.; Sintonen, S. Teacher education matters: Finnish teacher educators' concerns, beliefs, and values. Eur. J. Teach. Educ. 2019, 42, 211-227. [CrossRef]

23. Maslach, C. Burnout: The Cost of Caring; Prentice-Hall: Englewood Cliffs, NJ, USA, 1982.

24. Maslach, C.; Jackson, S.E. The measurement of experienced burnout. J. Organ. Behav. 1981, 2, 99-113. [CrossRef]

25. Kristensen, T.S.; Borritz, M.; Villadsen, E.; Christensen, K.B. The Copenhagen Burnout Inventory: A new tool for the assessment of burnout. Work Stress 2005, 19, 192-207. [CrossRef]

26. Carlsson, R.; Lindqvist, P.; Nordänger, U.K. Is teacher attrition a poor estimate of the value of teacher education? A Swedish case. Eur. J. Teach. Educ. 2019, 42, 243-257. [CrossRef]

27. Fiorilli, C.; Pepe, A.; Buonomo, I.; Albanese, O. At-risk teachers: The association between burnout levels and emotional appraisal processes. Open Psychol. J. 2017, 10, 127-139. [CrossRef]

28. Fiorilli, C.; Schneider, B.; Buonomo, I.; Romano, L. Family and nonfamily support in relation to burnout and work engagement among Italian teachers. Psychol. Sch. 2019, 56, 781-791. [CrossRef]

29. Darling-Hammond, L.; Hyler, M.E.; Gardner, M. Effective Teacher Professional Development; Learning Policy Institute: Palo Alto, CA, USA, 2017.

30. Avalos, B. Teacher professional development in Teaching and Teacher Education over ten years. Teach. Teach. Educ. 2011, 27, 10-20. [CrossRef]

31. Gorozidis, G.; Papaioannou, A.G. Teachers' motivation to participate in training and to implement innovations. Teach. Teach. Educ. 2014, 39, 1-11. [CrossRef]

32. Schaufeli, W.B.; Bakker, A.B. UWES- Utrecht Work Engagement Scale: Test Manual; Department of Psychology, Utrecht University: Utrecht, The Netherlands, 2003.

33. Pisanti, R.; Paplomatas, A.; Bertini, M. Misurare le dimensioni positive nel lavoro in sanità: Un contributo all'adattamento italiano della UWES-Utrecht Work Engagement Scale. [Measuring the positive dimensions among health care workers: A contribution to the Italian Validation of the UWES-Utrecht Work Engagement]. G. Ital. Med. Lav. Erg. 2008, 30, A111-A119.

34. Kline, R. Exploratory and confirmatory factor analysis. In Applied Quantitative Analysis in Education and the Social Sciences; Petscher, Y., Schatschneider, C., Compton, D.L., Eds.; Routledge: New York, NY, USA, 2013; pp. 183-217.

35. Veronese, G.; Pepe, A.; Dagdouke, J.; Addimando, L.; Yagi, S. Measuring well-being in Israel and Palestine: The subjective well-being assessment scale. Psychol. Rep. 2017, 120, 1160-1177. [CrossRef] [PubMed]

36. Veronese, G.; Pepe, A. Psychometric Properties of the Subjective Wellbeing Assessment Scale-French Version (SWBAS-18F): A Study With Young Refugees and Internally Displaced People in Nigerien Refugee Camps. J. Psychoeduc. Assess. 2020. [CrossRef]

37. Arbuckle, J.L. IBM ${ }^{\circledR}$ Amos TM 23 User's Guide; Amos Development Corporation: Chicago, IL, USA, 2014.

38. Tanaka, J.S. Multifaceted conceptions of fit in structural equation models. In Testing Structural Equation Models; Bollen, K.A., Scott-Long, J., Eds.; Sage Focus Editions: Newbury Park, CA, USA, 1993; Volume 154, pp. 10-39. 
39. Hu, L.; Bentler, P.M. Cutoff criteria for fit indexes in covariance structure analysis: Conventional criteria versus new alternatives. Struct. Equ. Model. Multidiscip. J. 1999, 6, 1-55. [CrossRef]

40. Chen, F.; Curran, P.J.; Bollen, K.A.; Kirby, J.; Paxton, P. An Empirical Evaluation of the Use of Fixed Cutoff Points in. Sociol Methods Res. 2008, 36, 462-494. [CrossRef]

41. Thakkar, J.J. Applications of SEM and FAQs. In Structural Equation Modelling. Studies in Systems, Decision and Control; Thakkar, J.J., Ed.; Springer: Singapore, 2020; pp. 101-112.

42. Gath, E.G.; Hayes, K. Bounds for the largest Mahalanobis distance. Linear Algebra Appl. 2006, 419, 93-106. [CrossRef]

43. Hakanen, J.J.; Bakker, A.B.; Schaufeli, W.B. Burnout and work engagement among teachers. J. Sch. Psychol. 2006, 43, 495-513. [CrossRef]

44. Prieto, L.L.; Soria, M.S.; Martínez, I.M.; Schaufeli, W. Extension of the Job Demands-Resources model in the prediction of burnout and engagement among teachers over time. Psicothema 2008, 20, 354-360.

45. Halbesleben, J.R.B.; Harvey, J.; Bolino, M.C. Too Engaged? A Conservation of Resources View of the Relationship Between Work Engagement and Work Interference With Family. J. Appl. Psychol. 2009, 94, 1452-1465. [CrossRef]

46. Harter, J.K.; Schmidt, F.L.; Hayes, T.L. Business-unit-level relationship between employee satisfaction, employee engagement, and business outcomes: A meta-analysis. J. Appl. Psychol. 2002, 87, 268-279. [CrossRef] [PubMed]

47. Hoxsey, D. Are happy employees healthy employees? Researching the effects of employee engagement on absenteeism. Can. Public Adm. 2010, 53, 551-571. [CrossRef] [PubMed]

48. Benevene, P.; Ittan, M.M.; Cortini, M. Self-Esteem and Happiness as Predictors of School Teachers' Health: The Mediating Role of Job Satisfaction. Front. Psychol. 2018, 9, 933. [CrossRef] [PubMed]

49. Gagné, M.; Deci, E.L. Self-determination theory and work motivation. J. Organ. Behav. 2005, 26, 331-362. [CrossRef]

50. Zimmermann, F.; Rösler, L.; Möller, J.; Köller, O. How learning conditions and Program structure predict burnout and satisfaction in teacher education. Eur. J. Teach. Educ. 2018, 41, 318-342. [CrossRef]

51. Passiatore, Y.; Pirchio, S.; Carrus, G.; Maricchiolo, F.; Fiorilli, C.; Arcidiacono, F. Intercultural practices and inclusive education in Europe: Can migration be a resource for individual and societal development? Eur. J. Psychol. Educ. 2019, 34, 209-224. [CrossRef]

52. Buonomo, I.; Fatigante, M.; Fiorilli, C. Teachers' Burnout Profile: Risk and Protective Factors. Open Psychol. J. 2017, 10, 190-201. [CrossRef]

53. Fiorilli, C.; Benevene, P.; de Stasio, S.; Buonomo, I.; Romano, L.; Pepe, A.; Addimando, L. Teachers' Burnout: The Role of Trait Emotional Intelligence and Social Support. Front. Psychol. 2019, 10, 2743. [CrossRef]

54. Buonomo, I.; Fiorilli, C.; Benevene, P. The impact of emotions and hedonic balance on teachers' self-efficacy: Testing the bouncing back effect of positive emotions. Front. Psychol. 2019, 10, 1670. [CrossRef]

55. Bakker, A.B.; Hakanen, J.J.; Demerouti, E.; Xanthopoulou, D. Job resources boost work engagement, particularly when job demands are high. J. Educ. Psychol. 2007, 99, 274-284. [CrossRef]

56. Chambers, G.; Coles, J.; Roper, T. Seeing it from both sides: Reasons for withdrawing from one-year secondary postgraduate certificate in education courses. Teach. Dev. 2002, 6, 373-390. [CrossRef]

57. Roness, D. Still motivated? The motivation for teaching during the second year in the profession. Teach. Teach. Educ. 2011, 27, 628-638. [CrossRef]

58. Skaalvik, E.M.; Skaalvik, S. Satisfaction, burnout and self-efficacy among teachers: A challenge for school leaders. In Skoleledelse. Betingelser for læring og ledelse iskolen [Management in schools. Conditions for learning and management in school]; Andreassen, R., Irgens, E.J., Skaalvik, E.M., Eds.; Tapir Akademisk Forlag: Trondheim, Norway, 2008; pp. 141-152.

59. Benevene, P.; de Stasio, S.; Fiorilli, C.; Buonomo, I.; Ragni, B.; Briegas, J.J.M.; Barni, D. Effect of teachers' happiness on teachers' health. The mediating role of happiness at work. Front. Psychol. 2019, 10, 2449. [CrossRef] [PubMed]

60. Buonomo, I.; Fiorilli, C.; Benevene, P. Unravelling Teacher Job Satisfaction: The Contribution of Collective Efficacy and Emotions Towards Professional Role. Int. J. Environ. Res. Public Health 2020, 17, 736. [CrossRef] [PubMed]

61. Howard, S.; Johnson, B. Resilient teachers: Resisting stress and burnout. Soc. Psychol. Educ. 2004, 7, 399-420. [CrossRef] 
62. Betoret, F.D. Stressors, self-efficacy, coping resources, and burnout among secondary school teachers in Spain. Educ. Psychol. 2006, 26, 519-539. [CrossRef]

63. Wideen, M.; Mayer-Smith, J.; Moon, B. A critical analysis of the research on learning to teach: Making the case for an ecological perspective on inquiry. Rev. Educ. Res. 1998, 68, 130-178. [CrossRef]

64. Ome, A.; Menendez, A.; Le, H.E. Improving teaching quality through training: Evidence from the Caucasus. Econ. Educ. Rev. 2017, 61, 1-8. [CrossRef]

65. Korthagen, F. Inconvenient truths about teacher learning: Towards professional development 3.0. Teach. Teach. 2017, 23, 387-405. [CrossRef]

66. Peterson, C.; Seligman, M.E.P. Values in Action (VIA): Classification of Strengths; Values In Action Institute: Philadelphia, PA, USA, 2000.

67. Zwart, R.C.; Korthagen, F.A.J.; Attema-Noordewier, S. A strength-based approach to teacher professional development. Prof. Dev. Educ. 2015, 41, 579-596. [CrossRef]

68. Hellström, T. Transferability and naturalistic generalization: New generalizability concepts for social science or old wine in new bottles? Qual. Quant. 2008, 42, 321-337. [CrossRef]

69. Lindell, M.K.; Whitney, D.J. Accounting for common method variance in cross-sectional research designs. J. Appl. Psychol. 2001, 86, 114-121. [CrossRef] [PubMed]

(C) 2020 by the authors. Licensee MDPI, Basel, Switzerland. This article is an open access article distributed under the terms and conditions of the Creative Commons Attribution (CC BY) license (http://creativecommons.org/licenses/by/4.0/). 